\title{
ISOLASI SENYAWA KUMARIN PADA TANAMAN
}

\author{
Dianti Pratiwi, Dila Qhoirul Nisa, Elsya Martia, Putri Wulanbirru, Syfa Dwi \\ Andini \\ Universitas Singaperbangsa Karawang (UNSIKA) Jawa Barat, Indonesia \\ Email: diantipra201@gmail.com,dilaqhoirul@gmail.com, elsyamrt@gmail.com, \\ wulanbirru03@gmail.com,syfadwiandini7@gmail.com
}

\begin{abstract}
Abstrak
Indonesia adalah negara yang kaya akan keanekaragaman hayati. Dari beberapa tanaman yang dapat dijadikan sebagai obat alternative untuk mengobati penyakit. Khasiat tumbuhan sebagai pengobatan dalam kesehatan terkait dengan tumbuhan memiliki senyawa kimia yang merupakan hasil metabolit sekunder yang terdapat di dalam tanaman tersebut. Salah satu golongan metabolit sekunder pada tumbuhan yaitu kumarin. Kumarin dapat ditemukan hampir di sebagian tumbuh-tumbuhan mulai dari akar, batang, daun, bunga dan juga buah. Tujuan penelitian ini dilakukan untuk mengisolasi dan mengidentifikasi senyawa kumarin yang terdapat di dalam tanaman tersebut. Pada proses senyawa isolasi kumarin yang dapat dilakukan dengan beberapa metode diantaranya esktraksi, skrining fitokimia, fraksinasi, isolasi kumarin dan identifikasi isolat. Tanaman yang mengandung senyawa kumarin yang digunakan pada isolasi kumarin yang kami review yaitu kulit buah limau sundai (Citrus nobilis Lour), biji buah rambutan (Nephelium lappaceum L), daun pacar air (Impatiens Balsemina Linn), kulit batang kecapi (Sandoricum koetjape) dan Artemisia annua L.
\end{abstract}

Kata Kunci: tanaman, isolasi kumarin, ekstraksi

\section{Abstract}

Indonesia is a country rich in biodiversity. Of several plants that can be used as alternative medicine to treat disease. The efficacy of plants as medicine in health is related to plants having chemical compounds which are the result of secondary metabolites contained in these plants. One of the secondary metabolites in plants is coumarin. Coumarins can be found in almost all plants from roots, stems, leaves, flowers and fruit. The purpose of this study was to isolate and identify coumarin compounds contained in these plants. In the process of isolating coumarin compounds that can be done by several methods including extraction, phytochemical screening, fractionation, isolation of coumarins and identification of isolates. Plants containing coumarin compounds that were used in the isolation of coumarins that we reviewed were sundai lime peel (Citrus nobilis Lour), rambutan fruit seeds (Nephelium lappaceum L), water henna leaves (Impatiens Balsemina Linn), harp bark (Sandoricum koetjape) and Artemisia annua L.

Keywords: plants, coumarin isolation, extraction

\begin{tabular}{ll}
\hline How to cite: & Pratiwi, Dianti, Dila Qhoirul Nisa, Elsya Martia, Putri Wulanbirru, Syfa Dwi Andini (2021) Isolasi \\
& Senyawa Kumarin Pada Tanaman, Syntax Idea, 3(7). https:// 10.36418/syntax-idea.v3i7.1375 \\
E-ISSN: & 2684-883X \\
Published by: & Ridwan Institute
\end{tabular}




\section{Pendahuluan}

Masyarakat Indonesia mengenal dan memakai tumbuhan sebagai suatu upaya penanggulangan masalah Kesehatan. Namun hal ini dilakukan berdasarkan pengalaman turun temurun bukan melalui kajian yang sistemis dan terencana, sehingga komponen kimia yang aktif dari tumbuhan tersebut belum banyak ditemukan (Zainol, Ronasari, \& Ninin Khoirunnisa, 2019).

Keanekaragaman hayati adalah sumber kekayaan yang sangat melimpah dan tak ternilai harganya. Keanekaragaam tersebut mempunyai kemmapuan untuk dikembangkan sebagai obat atau bahan baku obat, baik penggunaanya secara tradisional maupun modern. Setiap tumbuhan menghasilkan satu atau lebih senyawa bioaktif dengan dengan aktivitas tertentu, tumbuhan mengandung senyawa bioaktif dalam bentuk metabolit sekunder seperti alkaloid, flavonoid, steroid, terpenoid, tannin dan kumarin. Pada Keberadaan senyawa metabolit sekunder ini lah yang menyebabkan tumbuhan telah banyak digunakan sebagai obat, zat pewarna, perasa.

Tumbuhan merupakan organisme kompleks yang tersusun dari sel, sekelompok sel dengan bentuk dan fungsi yang sama membentuk jaringan, membentuk organ, sekelompok organ membentuk sistem organ dan akhirnya membentuk organisme (individu). Sekumpulan organisme yang sama akan membentuk populasi, dan populasi akan membentuk komunitas serta komunitas-komunitas yang berbeda dan akan berinteraksi dengan lingkungannya dalam suatu ekosistem. Tumbuhan adalah penghasil puluhan jenis senyawa organic yang digunakan untuk penghasil senyawa-senyawa berkhasiat (Dhaniaputri, 2016).

Senyawa kimia dalam tumbuhan adalah hasil metabolisme sekunder dari tumbuhan itu sendiri. Senyawa metabolit sekunder sangat bervariasi jumlah dan jenisnya dari setiap tumbuhan-tumbuhan. Beberapa dari senyawa tersebut telah diisolasi, Sebagian diantaranya memberikan efek fisiologi dan farmakologis yang lebih dikenal sebagai senyawa kimia aktif (Agustina, 2019). Kumarin merupakan salah satu golongan metabolit sekunder pada tumbuhan (Desi, 2016).

Senyawa organic kumarin diketahui memiliki aktivitas antiinflamasi, antioksidan, antialergi, antitrombotik, antivirus dan antikanker. Banyak studi eksperimental (Setiawan \& Rakhmawaty, 2014). Selain memiliki banyak aktifitas biologis kumarin dapat juga digunakan sebagai bahan dasar pembuatan parfum dan sebagai bahan flourisensi pada industry tekstil dan kertas (Murray, 1982). Kumarin banyak terdapat pada pada tumbuhan Angiospermae dan tidak jarang pada tumbuhan Gymnospermae serta tumbuhan tingkat rendah.

Isolasi yaitu suatu teknik pemisahan senyawa metabolit sekunder yang terdapat dalam suatu bahan alam. Isolasi senyawa pada bahan alam terdiri beberapa tahap yaitu ekstraksi, fraksinasi serta pemurnian dan identifikasi. Ekstraksi yaitu suatu proses pemisahan senyawa kimia yang terdapat dalam sampel bahan alam ke dalam pelarut. Prinsip metode ekstraksi didasarkan pada distribusi zat terlarut ke dalam pelarutnya, hasil ekstraksi ini disebut ekstrak. Fraksinasi yaitu proses pemisahan komponen dalam bentuk ekstrak menjadi fraksi-fraksi, proses ini dapat dilakukan dalam beberapa metode yaitu kromatrografi lapis tipis (KLT), kromatografi kolom, HPLC dan GC. Pemurnian 
dan identifikasi yaitu tahap akhir dalam isolasi teknik yang paling sederhana dan efektif untuk pemurnian senyawa metabolit sekunder yaitu kristalisasi atau rekristalisasi (Ilyas, 2013).

Kumarin sederhana yaitu fenilpropanoid yang mengandung cincin benzene C-6 dengan rantai alifatik C-3 dengan rumus molekul C9H5O2. Senyawa kumarin beserta turunannya mempunyai banyak aktifitas biologis yaitu sebagai antikoagulan darah, antibiotik dm, antimikroba, mempengaruhi kerja enzim sebgai bahan dasar pembuatan parfum serta untuk bahari fluorisensi pada industry tekstil dan kertas. Bentuk kumarin Kristal keping runcing, berbau harum, dapat mencair pada suhu $68^{\circ} \mathrm{C}-70^{\circ} \mathrm{C}$ dan dapat mendidih pada suhu $297^{\circ} \mathrm{C}-299^{\circ} \mathrm{C}$ (Zainol et al., 2019).

Turunan kumarin sintesis diperoleh dengan memodifikasi cincin kumarin secara kimia melalui reaksi substitusi yang dapat terjadi pada sisi dari 6 sisi yang tersedia pada molekul dasar yang memiliki struktur dan aktifitas yang bervariasi.

\section{Metode Penelitian}

Metode yang digunakan pada review ini merupakan suatu tinjauan literature (literature review) terhadap lima jurnal dan berdasarkan teori-teori yang relevan mengenai isolasi senyawa kumarin. Isolasi senyawa kumarin menggunakan metode ekstraksi, fraksinasi, pemurnian atau identifikasi dengan pelarut serta menggunakan cara yang berbeda-beda.

\section{Hasil dan Pembahasan}

Semua jurnal yang kami review pada isolasi senyawa kumarin menggunakan metode maserasi dan sokletasi. Menggunakan tanaman yang mengandung senyawa kumarin yaitu, Kulit buah Limau Sundai (Citrus nobilis Lour), biji buah rambutan (Nephelium lappaceum L.), daun pacar air ( Impatiens Balsamina Linn.), kulit batang kecapi (Sandoricum koetjape), dan Artemisia annua L. Tahapan Isolasi Senyawa Kumarin

1. Isolasi Senyawa Kumarin Kulit Buah Limau Sundai (Citrus nobilis Lour)

a. Ekstraksi

Ekstraksi dilakukan dengan metode maserasi, serbuk kering kulit buah Limau Sundai (Citrus nobilis Lour) sebanyak $5 \mathrm{~kg}$ direndam ke dalam maserator d menggunakan metanol lalu diaduk dan dibiarkan selama 5 hari pada suhu kamar. Kemudian disaring dan ditampung proses ini dilakukan berulang kali hingga uji negatif terhadap kumarin. Hasil ekstrak yang dimaserasi dikumpulkan lalu diuapkan pelarutnya dengan rotary evaporator Heidolp WB 2000 dan didapatkan ekstrak pekat.

b. Skrining Fitokimia

Hasil dari kromatografi kolom ditampung pada vial-vial dan dilakukan kromatografi lapis tipis dengan eluen yang sesuai dimana terbentuk Kristal, vial dengan hasil Rf yang sama digabung lalu dikristalisasikan dengan heksan dan etil asetat, dengan ditambahkan etil asetat kedalam padatan yang telah terbentuk, kemudian diaduk sampai larut. Selanjutnya ditambahkan heksan hingga keruh 
sehingga padatan mengendap kembali kemudian pelarut dipisahkan dari padatan. Cara ini dilakukan secara berulang sampai hasil yang didapatkan menjadi padatan yang bebas dari pengotor. Kemudian dilakukan kromatografi lapis tipis kembali, sehingga kromatogram memperlihatkan noda tunggal dengan intesitas fluoresensi biru yang kuat yang artinya isolat mengandung senyawa kumarin.

c. Fraksinasi

Fraksinasi etil asetat dimurnikan menggunakan metode kromatografi kolom, sebelumnya dimonitor terlebih dahulu dengan KLT untuk menemukan gradient eluen yang sesuai. Pengelusian dilakukan menggunakan fase gerak heksan, etil asetat dan metanol, hasil dari kromatografi kolom ditampung pada vial-vial serta dilakukan KLT lagi dengan eluen yang sesuai dimana terbentuk Kristal, vial dengan Rf yang sama digabung. Lalu direkristalisasikan dengan heksan dan etil asetat dengan menambahkan etil asetat pada padatan yang terbentuk kemudian diaduk hingga larut. Setelah itu ditambahkan heksan sampai terjadi kekeruhan, llau padatan mengendap kembali kemudian pelarut dipisahkan dari padatannya. Cara ini dilakukan secara berulang kali sampai hasil yang didapatkan menjadi padatan yang bebas dari pengotor.

d. Isolasi Kumarin

Senyawa yang diisolasi dari fraksi etil asetat kulit buah limau sundai merupakan senyawa kumarin, berbentuk kristal putih 2,159 g dengan titik leleh 126,2-127, $6^{\circ} \mathrm{C}$. Senyawa isolasi dikarakterisasi menggunakan spektroskopi UVVis, IR, C-NMR, 2D-NMR, (DEPT/HSQC, COSY, NOESY, HMBC). Dan dari data-data mendukung bahwa senyawa hasil isolasi adalah kumarin.

e. Identifikasi Isolat

Pengujian KLT yang di lakukan dengan lampu UV $365 \mathrm{~nm}$, yang berfluorisensi akan bertambah terang dengan dilakukan penambahan $\mathrm{NaOH} 10 \%$, hasil senyawa isolasi dari fraksi etil asetat kulit buah Citrus nobilis Lour yaitu senyawa kumarin, dari data-data analisa Spektroskopi UV-Vis, IR, C-NMR, HNMR, 2D-NMR (DEPT/HSQC, COSY, NOESY, HMBC), untuk hasil dari senyawa isolasi adalah marmin.

2. Isolasi Senyawa Kumarin dari Biji Buah Rambutan (Nephelium lappaceum L.)

\section{a. Ekstraksi}

Ekstraksi Serbuk biji N. lappaceum sebanyak $5 \mathrm{~kg}$ dengan menggunakan teknik maserasi menggunakan metanol.Maka untuk dilakukan Ekstraksi harus selama $3 \times 24$ jam, lalu hasil ekstrak tersebut disaring dan dipisahkan antara filtrat dan residunya. Ekstrak metanol yang diperoleh juga dipekatkan dengan rotary evaporator dan ditimbang untuk memperoleh massa dari ekstrak kental. Kemudian Ekstrak metanol kental dilarutkan di dalam metanol, kemudian dipartisi dengan menggunakan pelarut n-heksana dan etil asetat. Hasil Ketiga partisi dipekatkan menggunakan rotary evaporator sehingga memperoleh fraksi n-heksana, fraksi etil asetat dan fraksi metanol. 
b. Skrining Fitokimia

Hasil yang di peroleh dari Fraksi etil asetat dengan dilakukan uji fitokimia. Untuk mengidentifikasi golongan fenolik yaitu dengan penambahan $\mathrm{FeCl} 3$ maka akan memberikan perubahan warna menjadi hijau kehitaman dari warna kuning. Perubahan warna tersebut disebabkan karena senyawa fenolik jika bertemu dengan Fe maka akan membentuk senyawa yang kompleks.

c. Fraksinasi

Fraksi etil asetat dilakukan KVC, proses elusi dimulai dengan menggunakan kombinasi eluen berdasarkan KLT yang dimulai dari 100\% n-heksan, nheksan:etil asetat $(8: 2,6: 4,2: 8) 100 \%$ etil asetat. Etil asetat:methanol (9:1, 8:2) dan 100\% methanol. Eluat di KLT dengan eluen n-heksan:etil asetat (4:6). Fraksinasi yang diperoleh dari hasil gabungan KVC sebanyak 7 fraksi dengan kode $\mathrm{S}_{1-7}$.Fraksi $\mathrm{S}_{4}$ hasil KVC dilakukan KKG. Proses elusi dimulai dari pelarut yang diperoleh dari KLT yaitu 100\% kloroform, kloroform:methanol (99:1, 97:3, 95:5, 90:10, 70:30) dan 100\%. Hasil dari KLT, yang mengandung senyawa target dan cukup murni pada fraksi $\mathrm{S}_{4} \mathrm{~N}_{23}$ kemudian dilanjutkan uji kemurnian.

d. Isolasi Kumarin

Pada pengelusian KVC dilakukan secara bergradien dan dilakukan pengulangan sebanyak dua kali, bertujuan agar senyawa yang terpisah semakin baik. Fraksi yang diperoleh dapat dilakukan dengan menggunakan metode KLT, fraksi-fraksi yang memiliki noda dan RF yang relatif sama digabungkan. Dari hasil penggabungan 51 fraksi menghasilkan 7 fraksi gabungan. Dari Ketujuh fraksi yang dilakukan dengan metode KLT lalu kembali dengan eluen nheksana:etil asetat.

e. Identifikasi Isolat

Analisis spectrum MS menunjukkan berat molekul isolat $\mathrm{S}_{4} \mathrm{~N}_{23}$. Berat molekul yang didapat sesuai dengan rumus molekul $\mathrm{C}_{15} \mathrm{H}_{16} \mathrm{O}_{8}$, bila dikombinasikan dengan hasil NMR- ${ }^{1} \mathrm{H}$ dan COSY didapat senyawa 5-O- $\alpha-\mathrm{L}-$ ramnosa-7-hidroksikumarin.

Hasil uji fitokimia terhadap fraksi $\mathrm{S}_{4} \mathrm{~N}_{23}$ biji buah $N$. lappaceum diketahui bahwa positif mengandung senyawa fenolik. Senyawa dengan golongan fenolik salah satunya adalah kumarin, maka reaksi positif golongan senyawa fenolik diduga dari senyawa tersebut. Berdasarkan KLT yang telah dilakukan, diperoleh $\mathrm{RF}<2$ dengan pelarut $\mathrm{n}$-heksan:etil asetat hal ini menunjukkan senyawa bersifat polar yang diduga karena adanya gugus gula terikat pada senyawa fenol.

3. Isolasi Senyawa Kumarin dari Daun pacar Air (Impatiens Balsamina Linn.)

a. Ekstraksi

Daun pacar air dirajang halus lalu dikeringkan dengan cara di anginkan. Sebanyak 600 gram sampel kering disokletasi dengan n-heksa (5L), setelah pelarut tidak berwarna lagi maka proses sokletasi dilanjutkan dengan pelarut etil asetat dan metanol berturut turut . Ekstrak diuapkan pelarutnya dengan rotary evaporator, maka akan didapat ekstrak pekat n-heksana, ekstrak pekat etil asetat dan methanol. 
b. Skrining Fitokimia

larutan ekstrak ditotolkan pada plat KLT. Eluen yang digunakan adalah nheksan dan etil asetat dengan perbandingan 3:1. Ketika dilihat pada UV $366 \mathrm{~nm}$ bercak noda tersebut Nampak berwarna biru.

\section{c. Fraksinasi}

Fraksi etil asetat dikukan KVC. Proses elusi dimulai dengan menggunakan kombinasi eluen berdasarkan KLT yang dimulai 100\% n-heksana, n-heksana : etil asetat $(8: 2,6: 4,4: 6,2: 8)$. Eluat yang berada di KLT dengan eluen n-heksana:etil asetat (4:6). Fraksi yang diperoleh dari hasil gabungan KCV sebanyak 7 fraksi. Proses eluesi dimulai dari pelarut yang diperoleh dari KLT yaitu 100\% kloroform, kloroform:methanol dan 100\% methanol. Eluat yang berada di KLT dengan eluen n-heksana:etil asetat (35:65). Hasil dari gabungan KKG sebanyak 30 fraksi. Hasil dari KLT, yang mengandung senyawa target dan cukup murni pada fraksi S4N23.

d. Isolasi Kumarin

Untuk menentukan senyawa isolasi maka terlebih dulu sifat fisikanya yang meliputi uji titik leleh dan kromatografi lapis tipis dengan berbagai eluen. Isolasi dari daun pacar air ini didapati kristal berwarna kuning seberat $7 \mathrm{mg}$ dengan titik leleh $182-183^{\circ} \mathrm{C}$. Berdasarkan titik lelehnya, data spektrum UV dan IR, termasuk dalam senyawa isolasi golongan 1,4 naftaquinon yang terabsubstitusi gugus metoksi.

e. Identifikasi Isolat

Fraksi etil asetat dengan metode KLT menggunakan penampak noda $\mathrm{NaOH}$ $10 \%$ menunjukkan satu noda berwarna merah bata, berarti fraksi etil asetat ini positif mengandung senyawa kuinon. Dari Plat KLT yang disinari dengan lampu UV 365 nm akan memberikan warna fluoresensi kuning hijau, biru, kuning hijau dan kuning. Informasi Dari data yang diperoleh bahwa selain senyawa kuinon fraksi etil asetat juga mengandung senyawa kumarin dan flavonoid.

4. Isolasi senyawa kumarin dari Kulit Batang Kecapi (Sandoricum koetjape)

a. Ekstraksi

Sebanyak 900 gram serbuk kulit batang kecapi direndam dengan menggunakan pelarut heksana, etil asetat dan metanol dilakukan dengan metode maserasi berkali-kali dengan menggunakan pelarut tersebut. Ekstrak yang akan didapatkan yaitu dengan cara diuapkan dengan rotary evaporator hingga didapatkan ekstrak pekat. Diperoleh ekstrak pekat heksana 36,75 gram, etil asetat 37,57 gram dan methanol 36,83 gram.

b. Skrining Fitokimia

Uji kandungan metabolit sekunder (Fitokimia) yang telah dilakukan pada kulit batang bahwa selain mengandung senyawa triterpenoid juga terdapat flavonoid, fenolik dan kumarin. Senyawa kumarin dari kulit batang kecapi dilakukan identifikasi senyawa dengan menggunakan spektroskopi IR. 


\section{c. Fraksinasi}

Fraksi heksana dilakukan dengan cara rekromatografi kolom dan dilakukan dengan penggabungan fraksi yang berdasarkan pola noda Rf yang sama sehingga didapatkan 4 fraksi. Lalu diperoleh senyawa murni yang ditandai dengan adanya noda tunggal pada plat KLT. Adanya terlihat kontaminasi dari hasil sphadex LH20 maka dimurnikan kembali dengan menggunakan KLT preparative. Senyawa murni yang didapatkan di KLT tersebut menggunakan berbagai perbandingan eluen.

\section{d. Isolasi Senyawa Kumarin}

Hasil pengujian dari titik leleh yang didapatkan yaitu titik leleh dari senyawa ini adalah 194 - 195. Jaungkauan nilai titik leleh maka diindikasikan senyawa hasil isolasi telah murni. Sedangkan untuk titik leleh senyawa dari hasil isolasi pada penelitian sebelumnya adalah terdekomposisi pada suhu 220. Senyawa hasil isolasi berupa Kristal jarum berwarna putih yang diperoleh dari ekstrak etil asetat dengan titik leleh 194 - 195. Hasil pengukuran spektroskopi inframerah memperlihatkan pita serapan.

e. Identifikasi Isolat

Pada identifikasi senyawa dilakukan dengan spektroskopi IR. Pada spectrum senyawa hasil isolasi yang didapatkan, hasil pengukuran spektroskopi inframerah memperlihatkan pita serapan pada panjang gelombang $3339 \mathrm{~cm}-1,2946 \mathrm{~cm}-1$, $1702 \mathrm{~cm}-1,1509 \mathrm{~cm}-1,1446 \mathrm{~cm}-1$ dan $1018 \mathrm{~cm}-1$. Dari hasil data spektroskopi IR menunjukkan bahwa senyawa ini memiliki gugus fungsi hidroksil.

5. Senyawa Isolasi dari Artemisia aпnиa $L$

a. Ekstraksi

Sampel diekstraksi menggunakan alat soklet pendingin baik dengan pelarut metanol dilakukan sebanyak 2 kali dalam sehari sampai semua sari terekstrak, dihasilkan larutan yang tidak berwarna lagi atau bening. Kemudian ektrak dipekatkan menggunakan rotary evaporator sampai ekstrak mengental, lalu dikeringkan menggunakan waterbath suhu $40^{\circ} \mathrm{C}-45^{\circ} \mathrm{C}$ hingga ektrak kental.

b. Skrining

Fraksi diklormetan dan standar baku kumarin dilakukan uji KLT menggunakan fase diam silica gel GF 254 dan fase gerak campuran-heksana: etil asetat dengan perbandungan 2:2. Hasil KLT yang dideteksi dengan menggunakan detector UV pada panjang gelombang $366 \mathrm{~nm}$, selanjutnya dilakukan penetapan kadar kumarin dalam sampel menggunakan alat densitometer.

c. Fraksinasi

Ekstrak kental dilarutkan dengan aquadest sampai semua ekstrak larut, lalu dimasukan kedalam corong pisah $500 \mathrm{ml}$. Kemudian ditambahkan pelarut diklormetan kedalam corong tersebut sampai terbentuk 2 lapisan, setelah terbentuk lalu dipisahkan melalui fraksi diklormetan menghasilkan warna hijau pekat dan fraksi methanol air menghasilkan warna coklat muda. 
d. Isolasi senyawa kumarin

Senyawa Kumarin yang terdapat fraksi diklormetan menggunakan hasil uji KLT yang terdeteksi dari lampu UV dengan panjang gelombang $366 \mathrm{~nm}$ dengan fraksi diklormetan terdapat Rf dihasilkan bercak bulat flourisensi biru terang dan hasilnya sama seperti pada hasil uji KLT standar kumarin.

e. Identifikasi isolate

Ekstrak artemisia апnиa $L$ diidentifikasi senyawa kumarin dengan menginjeksikan larutan yang mengandung fraksi diklorometan dan larutan mengandung methanol-air. Kemudian pada plat KLT dilakukan elusidasi menggunakan fase gerak campuran n-heksana: etil asetat perbandingan 2:2 menghasilkan nilai Rf bercak serta warna yang didapat dari standar kumarin.

Identifikasi kumarin yang dihasilkan secara KLT dengan eluen n-heksan: etil asetat perbandingan 2:2, Rf yang dihasilkan berwarna biru flouriensi dilihat pada lampu UV dengan panjang gelombang $366 \mathrm{~nm}$. Sedangkan pada fraksi (tidak ada kumarin) tidak terjadi pemisahan dan terdapat bercak hitam. Sedangkan pada fraksi methanol-air tidak mengandung senyawa kumarin karena pada fraksi tersebut semua senyawa kumarin telah tertarik kedalam fraksi diklormetan.

\section{Kesimpulan}

Kumarin adalah senyawa fenol yang berasal dari tanaman tinggi dan jarang ditemukan pada mikroorganisme. Senyawa kumarin beserta turunanannya mempunyai banyak aktifitas biologis yaitu sebagai antikoagulan darah, antibiotic, antimikroba, mempengaruhi kerja enzim. Kumarin berbentuk kristal keeping runcing, berbau harum, dapat mencair pada suhu $68^{\circ} \mathrm{C}-70^{\circ} \mathrm{C}$ dan dapat mendidih pada suhu $297^{\circ} \mathrm{C}-299^{\circ} \mathrm{C}$. Dari jurnal yang kami review, digunakan lima tanaman tersebut dilakukan uji isolasi senyawa kumarin. Ekstraksi merupakan isolasi senyawa dalam suatu campuran larutan atau padatan dengan menggunakan pelarut yang sesuai, sedangkan Fraksinasi merupakan proses pemisahan komponen senyawa berdasarkan tingkat kepolarannya. Pada proses ekstraksi senyawa menggunakan metode maserasi dan sokletasi, pelarut senyawa kumarin yang digunakan methanol, etanol, N-heksan. Pada proses fraksinasi senyawa menggunakan metode KKG, KLT, dan KVC. Identifikasi Isolat menggunakan spektroskopi UV-Vis, Spektroskopi IR dan KLT. Dari hasil tanaman tersebut dapat disimpulkan mengandung senyawa kumarin. 
Dianti Pratiwi, Dila Qhoirul Nisa, Elsya Martia, Putri Wulanbirru, Syifa Dwi Andini

\section{BIBLIOGRAFI}

Agustina, Ratna. (2019). Efektifitas Ekstrak Daun Jambu Biji (Psidium Guajava L.) Terhadap Bakteri Aeromonas hydrophila SECARA IN VITRO (Studi Eksperimen Sebagai Sumber Belajar Peserta Didik Pada Materi Sistem Imun Pada Hewan Untuk Sekolah Menengah Atas Kelas IX Semester II). UIN Raden Intan Lampung.Google Scholar

Antira. Nurdin. Santoni. (2013). Uji Antioksidan dari Ekstrak Daun Surian. Makara Sains:2(23):119-123. Google Scholar

Desi, Karmila. (2016). Isolasi Senyawa Metabolit Sekunder dari Fraksi Etil Asetat Tumbuhan Rumput Mutiara (Hedyotis corymbosa L.) dan Uji Toksisitas dengan Metode Brine Shrimp Lethality Test (BSLT). Universitas Andalas. Google Scholar

Dhaniaputri, Risanti. (2016). Mata Kuliah Struktur dan Fisiologi Tumbuhan sebagai Pengantar Pemahaman Proses Metabolisme Senyawa Fitokimia. Research Report. Google Scholar

Fitriyah, Indatul. Thahjandarie, Tjitik. Saputri, Ratih. (2021). Aktivitas Kanker Senyawa Turunan Kumarin dari Melicope Latifolia. Jurnal Sains:15(1):1-7. Universitas Airlangga.

Febria Elvi, Susanti. Mai, Efendi. (2016). Isolasi Senyawa Kumarin dari Kulit Batang Kecapi. Jurnal Kalisator:1(2):1-8. Universitas Andalas. Google Scholar

Ilyas, Asriani. (2013). Senyawa Golongan 2-arylbenzofuran dan Stilben dari Ekstrak Metilen Klorida $(\mathrm{CH} 2 \mathrm{Cl} 2)$ Daun Artocarpus fretessi hassk. Teknosains: Media Informasi Sains Dan Teknologi, 7(1), 1-9. Google Scholar

Katja, Dewa. Sonda, Andre. Huspa, Maryanti. (2015). 7-Hidro-6-Metoksi Kumarin dari Kulit Batang Chisocheton Celebius. Jurnal Kimia:9(2):267-270. Universitas Padjajaran. Google Scholar

Khafidhoh, Zakiyatul. Dewi, Sri. (2015). Efektivitas Infusa Kulit Jeruk Purut terhadap Pertumbuhan Candida albicans Penyebab Sariawan secara in vitro. Universitas Muhammadiyah Semarang. Google Scholar

Khasanah, Sisca. Imaniah, Nur. Saputri, Ratih. (2018). Antioksidan Kumarin Terisoprenilasi dan Alkaloid indol dari Kulit Batang Zanthoxylum Ovalifolium Tutcher. Jurnal Kimia:15(2):79-81. Universitas Airlangga. Google Scholar

Mulia, Melindra. Isolasi Kumarin dari Kulit Buah Limau Sundai. (2017). Jurnal Eksakta:18(2):138-145. Universitas Negeri Padang. Google Scholar

Setiawan, Duyeh, \& Rakhmawaty, Diana. (2014). Sintesis Dan Karakterisasi Senyawa 3, 3'-Benzilidena Bis-4-Hidroksi Kumarin Untuk Sediaan Radioterapi. Chimica et Natura Acta, 2(3). Google Scholar 
Sukmawati, Siti Nurhajar. Harlia. Rudiyansyah. (2017).Jurnal JJK. Karakterisasi Struktur Senyawa Kumarin Glikosida Dari Biji Buah Rambutan (Nephelium lappaceum L.). Pontianak: Program Studi Kimia Universitas Tanjung Pura. 6(3):15.

Wibaldus. Jayuska, Afghani. (2016). Bioaktivitas Minyak Atsiri Kulit Jeruk Nipis terhadap Rayap Tanah. JKK:5(1):44-51. Universitas Tanjung Pura. Google Scholar

Wesly, Pasaribu. sammy. longdong. (2015). efektivitas Estrak Daun Pacar Air untuk Meningkatkan Respon Imun Non Spesifik Ikan Nila. jurnal Budidaya Perairan;3(1):83-92. Manado. Google Scholar

Zainol, Arifin, Ronasari, Mahadji Putri, \& Ninin Khoirunnisa, Ninin. (2019). Similarity Jamu Tradisional Ditinjau dari Aspek Ekonomi dan Kesehatan. Google Scholar

\section{Copyright holder :}

Dianti Pratiwi, Dila Qhoirul Nisa, Elsya Martia, Putri Wulanbirru, Syifa Dwi Andini (2021)

First publication right :

Syntax Idea

This article is licensed under:

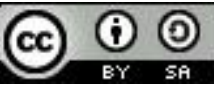

